* Mestre em Direito Negocial pela Universidade Estadual de Londrina (UEL). E-mail: baleotti@uel.br

** Doutor em Direito pela Pontifícia Universidade Católica de São Paulo (2004). Email: baleotti@uel.br

\section{Impactos da morosidade judicial na atividade empresarial e a busca de soluções}

\author{
IMPACTS OF JUDICIAL DELAY ON COMPANIES' \\ ACTIVITY AND THE SEARCH FOR SOLUTIONS
}

\author{
João Carlos Leal Júnior * \\ Francisco Emilio Baleotti **
}

Resumo: Com a promulgação da emenda constitucional $n^{\circ} 45$ / 04, o direito à razoável duração do processo foi incluído, sob a forma de norma principiológica, no rol de direitos fundamentais da Constituição brasileira. O desígnio do constituinte foi alcançar celeridade no trâmite do processo, o qual, por sua vez, constitui instrumento para concretização de direitos. A realização do princípio em questão é essencial para o real acesso à ordem jurídica justa, imperativo igualmente de assento constitucional. Todavia, no cenário brasileiro contemporâneo, o que se tem, em verdade, é indiscutível lentidão no trâmite processual. No âmbito empresarial, os impactos da morosidade da resposta estatal são incomensuráveis, representando prejuízo para as empresas e para os interesses que para ela convergem, além de gerar óbices para a inserção do país no mercado global, objetivo tão almejado na contemporaneidade. A incorporação de elementos e técnicas existentes no sistema processual inglês pode se mostrar útil na agilização procedimental e consequente mitigação dos impactos em comento.

Palavras-chave: Razoável duração do processo; acesso à justiça; negócios empresariais; processo civil inglês.

Abstract: By the promulgation of constitutional amendment $45 / 04$, the right to a reasonable duration of proceedings has been included, as a principle, among the fundamental rights of Brazilian Federal Constitution. The constitutional intent was to mitigate the delay in the duration of procedure, which, in its turn, is an instrument to concrete rights. The realization of that principle is essential to a real access to justice, equally a constitutional imperative. However, there is, currently, in Brazil, in fact, an indubitable delay in the procedures duration. Within business context, the impacts of judicial delay are incommensurate, representing damage to companies and to the interests that converge to it, besides generating obstacles for the country's insertion in the global market. The incorporation of elements and techniques available in English procedure system may be helpful in procedural speeding up and consequent mitigation of the impacts in discussion.

Keywords: Reasonable duration of procedures; access to justice; corporate business; English civil procedure. 


\section{INTRODUÇÃO}

O princípio sobre o qual se assenta o reconhecimento e a busca pela proteção dos direitos humanos é "la garantía de la dignidad del ser humano a través de ciertos derechos mínimos que les son reconocidos a los individuos en su sola condición de seres humanos" (ROJAS, 2008, p.41). Com isso, "la idea original de los derechos individuales se fortalece $y$ pasa a constituir una categoría especial de derechos subjetivos, con protección no sólo nacional, sino que internacional" (ROJAS, 2008, p.41).

Nesta senda, sabe-se que inúmeros documentos internacionais foram criados tendo por meta a proteção desses direitos mínimos a fim de salvaguardar e efetivar a dignidade inerente aos seres humanos. A Declaração Universal dos Direitos Humanos, adotada e proclamada pela Assembléia Geral das Nações Unidas em 10 de dezembro de 1948, é o exemplo mais característico do que se afirma. Em seu artigo X, consagrou como direito humano o princípio do acesso à justiça, ao dispor que "toda pessoa tem direito, em plena igualdade, a uma audiência justa e pública por parte de um tribunal independente e imparcial, para decidir de seus direitos e deveres [...]" [grifo nosso].

Complementando a ideia, o artigo VIII consigna que, ademais, toda pessoa tem direito a receber dos tribunais nacionais competentes remédio efetivo para os atos que violem os direitos fundamentais que the sejam reconhecidos pela constituição ou pela lei.

Vislumbra-se neste espaço, então, direitos humanos impositivos que trouxeram os contornos do acesso à justiça, ou acesso à ordem jurídica justa, incorporado como direito fundamental na Constituição brasileira de 1988. Do ponto de vista do direito internacional, o sistema de codificação dos direitos e o estabelecimento dos mecanismos de controle buscam consagrar uma ordem pública global centrada na ideia de direitos humanos para garanti-los na realidade de cada país. Assim, "la preocupación por la situación de los individuos pasa a ser un tema de interés para toda la comunidad internacional y escapa de los límites de la soberanía de los Estados" (ROJAS, 2008).

$\mathrm{O}$ acesso à justiça, então, é tido como direito humano e fundamental, na medida em que é garantido por documentos internacionais dos quais o Estado brasileiro é signatário, assim como pela Constituição de 1988, razão pela qual esforços devem ser feitos para que seja efetivado, deixando de constituir mero texto normativo. 
Entretanto, a morosidade do Poder Judiciário brasileiro se coloca como fator impeditivo da efetivação do acesso à ordem jurídica justa. Sem embargo da inovadora previsão do direito à razoável duração do processo e das frequentes reformas processuais em vistas à sua implementação, o que se tem no cenário brasileiro contemporâneo é uma infinidade de processos judiciais, especialmente de natureza civil, para serem julgados por juízes e tribunais insuficientes à demanda existente.

Não bastasse isso, em controvérsias relacionadas a negócios empresariais, a demora na pacificação do conflito gera drásticas repercussões, especialmente de cunho econômico, o que é prejudicial à inserção do país no mercado global. Neste sentido, devem ser empreendidas reformas voltadas à diminuição da demasiada duração processual e à consectária concessão de tutela jurisdicional à parte em tempo razoável, de forma a superar esses impactos negativos, que serão analisados neste estudo.

O sistema processual civil inglês será utilizado como paradigma no que tange à celeridade e à efetividade da tutela jurisdicional, notadamente após o advento das Civil Procedure Rules, na busca de serem incorporadas no cenário brasileiro proficuidades agora lá existentes.

\section{O ACESSO À JUSTIÇA COMO DIREITO HUMANO FUNDAMENTAL}

Consoante a lição de Mauro Cappelletti e Bryan Garth (1988, p.8), embora a expressão "acesso à justiça" seja reconhecidamente de difícil definição, serve para determinar "o sistema pelo qual as pessoas podem reivindicar seus direitos e/ou resolver seus litígios sob os auspícios do Estado”. Em razão disso, impõese que o sistema seja igualmente acessível a todos e que ele produza resultados que sejam individual e socialmente justos.

Assim, ultrapassando o mero acesso às vias processuais, a garantia contida no inciso XXXV do artigo $5^{\circ}$ da vigente Constituição constitui verdadeiro imperativo de efetivação da justiça, tendo por objetivo conceder provimento adequado às demandas judiciais, tomando em conta o direito material em discussão. Exsurge, então, o princípio do acesso à ordem jurídica justa, que significa a realização de justiça aos que a requerem, possibilitando, de forma real, ao cidadão que vivencie um contexto de segurança jurídica, onde o direito é efetivamente realizado (LEAL JÚNIOR; BALEOTTI, 2011). 
Em outras palavras, impõe a recomposição de um direito violado ou a cessação de ameaça quando pendente sobre ele (BUENO, 2010).

A grandeza do princípio na Constituição de 1988 é evidenciada pela previsão de tutela jurisdicional mesmo em situações em que inexista lesão: a mera ameaça a direito já possibilita a movimentação do Judiciário em ordem à obtenção de comando protetivo. Objetiva-se impedir que a ameaça chegue a lesar o direito, e isso se mostra essencial, especialmente no que tange à tutela de interesses metaindividuais, já que a reparação, nesse campo, em grande parte das vezes não se mostra possível, de forma que a lesão deve ser prevenida (BUENO, 2010)..

Deste modo, para que esta meta constitucional seja atingida na sede ordinária de resolução de conflitos - a Jurisdição -, impõe-se que o processo judicial se desenrole mediante cognição adequada e que tenha razoável duração em seu trâmite, evitando o perecimento do direito, acarretado pela morosidade da prestação jurisdicional.

Reconhece-se, desta feita, o caráter instrumental do processo, como instituto voltado à realização da justiça (BEDAQUE, 2011) e coloca-se, consequentemente, a função social do processo como estandarte da revolução instrumentalizadora, que redefiniu os contornos axiológicos procedimentais, a fim de conferir ao processo a posição de ferramenta para a concretização da justiça, viabilizando que o Estado cumpra seu dever de dirimir conflitos de interesses e promover a pacificação social, desprendendose de formalismos sobejos e da irracional busca de exaurimento probatório, sob o risco de fenecimento do direito.

A patente lentidão do Poder Judiciário brasileiro é matéria de discussão exaustiva na doutrina, assim como a necessidade de conjugação de medidas para a efetivação dos direitos buscados judicialmente, sendo insofismável que um processo que se estende por anos não compraz a nenhuma das partes litigantes, gerando insegurança e desprestigiando o sistema legal. O acesso à justiça ganha importância capital neste contexto, encarado modernamente como direito humano fundamental e imprescindível a um sistema jurídico de vanguarda que pretenda efetivar, "e não apenas proclamar os direitos de todos" (CAPPELLETTI; GARTH, 1988, p.12). Este enfoque atual é a nota característica do estudo do processo civil contemporâneo.

O direito fundamental em apreço constitui o ponto fulcral do princípio da dignidade da pessoa humana, porque essencial para a concretização dos demais 
direitos quando obstaculizados. Em virtude de seu realce, pode ser concebido como a base da processualística moderna.

Tem-se, então, que o acesso à justiça não se limita à dimensão puramente formal. Ao revés, propugna pela "efetividade dos direitos materiais e a concretização das garantias processuais constitucionais" (PAROSKI, 2006, p.226), de forma que seja concedida concretamente a tutela jurisdicional adequada, tempestiva e efetiva ao litigante cuja razão o ordenamento jurídico reconhecer.

Enfim, efetividade, adequação e tempestividade são qualitativos imprescindíveis ao provimento jurisdicional para que se concretize substancial acesso à ordem jurídica justa.

\section{A RAZOÁVEL DURAÇÃO DO PROCESSO COMO COROLÁRIO INAFASTÁVEL DO ACESSO À JUSTIÇA}

A importância da duração razoável do processo, tanto nas vias judiciais quanto administrativas, fez a emenda $n^{\circ}$ 45/2004 elevar o princípio à categoria de direito fundamental e garantia constitucional, no inciso LXXVIII do artigo $5^{\circ}$ da Constituição.

Trata-se do direito de se exigir eficiência e prontidão da resposta estatal à provocação ocorrida, por meio de demanda intentada, dentro de prazo razoável. Tem-se manifestação da busca pelo respeito à dignidade da pessoa humana, assim como ocorre com os demais direitos fundamentais, evidentemente, mas com especial peculiaridade, posto estar vinculado à realização da prestação jurisdicional, que é por meio da qual se busca a aplicação in concreto do Direito.

O princípio em comento já constava, expressa ou tacitamente, de diplomas constitucionais de diversos países, tais como México, Portugal e Espanha, não sendo, portanto, inovação brasileira. Neste sentido, a Constituição mexicana de 1917 adota a obrigatoriedade de obediência aos prazos processuais contidos em lei; a portuguesa, em seu artigo 20, itens 4 e 5, determina que as decisões sejam proferidas em prazo razoável, devendo os procedimentos judiciais pautarem-se por celeridade e prioridade. Os Estados Unidos, por seu turno, têm, em sua Constituição, após inclusão da $6^{\mathrm{a}}$ emenda, a determinação da chamada cláusula de julgamento rápido - ou speedy trial clause, no idioma pátrio -, que garante o direito subjetivo do indivíduo à jurisdição célere. A carta italiana (art. 111) impõe que a lei assegure a "ragionevole durata del processo". A Constituição Espanhola (art. 24, 2) exige "proceso público sin dilaciones 
indebidas", respeitadas todas as garantias constitucionais processuais. Finalmente, a Constituição da Venezuela de 1999, em seu artigo 49, 3, prevê que "toda persona tiene derecho a ser oída en cualquier clase de proceso, con las debidas garantías y dentro del plazo razonable determinado legalmente por un tribunal competente, independiente e imparcial establecido con anterioridad [...] [grifo nosso]", e coloca, ademais, como atribuição do Ministério Público, garantir a celeridade processual (art. 285, 2).

Mais recentemente, seguindo a tendência aventada, a nova Consituição equatoriana, de 2008, previu, em seu artigo 75 que "toda persona tiene derecho al acceso gratuito a la justicia y a la tutela efectiva, imparcial y expedita de sus derechos e intereses, con sujeción a los principios de inmediación y celeridad [...]"; e prossegue no artigo 86: "las garantías jurisdiccionales se regirán, en general, por las siguientes disposiciones: [...] 2. [...] serán aplicables las siguientes normas de procedimiento: a) El procedimiento será sencillo, rápido y eficaz. [...]" [grifo nosso].

A Constituição da Bolívia, promulgada em 2009 após referendo popular ao qual foi submetida, igualmente tutelou o direito a uma resposta estatal tempestiva em seu artigo 118: "I. Toda persona será tutelada oportuna y efectivamente por los jueces y tribunales en el ejercicio de sus derechos e intereses legítimos. II. El Estado garantizará el derecho al debido proceso, a la defensa y a una justicia plural, pronta, oportuna, gratuita, transparente, y sin dilaciones". No artigo 190, complementou: "I. La jurisdicción ordinaria se fundamenta en los principios procesales de gratuidad, publicidad, transparencia, oralidad, celeridad, probidad, honestidad, legalidad, eficiencia, accesibilidad, inmediatez, verdad material y debido proceso" [grifo nosso].

O fomento à consagração, nas Constituições, deste direito deve-se à previsão dele em tratados versantes sobre direitos humanos, que já vinha ocorrendo desde o século XX. Nesse sentido, podem ser citados a Convenção Europeia pela Salvaguarda dos Direitos do Homem e das Liberdades Fundamentais (art. 6 ${ }^{\circ}$, I), de 1950; o Pacto Internacional sobre Direitos Civis e Políticos (art. 14, 2, c - porém limitado à matéria penal), de 1966; o Pacto de San Jose da Costa Rica (art. 8, I), de 1969; e a Carta dos Direitos Fundamentais da União Europeia (art. 47), de 2000. O respeito à duração razoável tornou-se exigência em âmbito internacional, tanto que seu descumprimento tem gerado condenações de Estados (Itália e Espanha, por exemplo), em julgamentos realizados por Cortes Internacionais, como o Tribunal Europeu de Direitos Humanos e mesmo a Corte Interamericana de 
Direitos Humanos, às decisões da qual o Brasil deve deferência (LEAL JÚNIOR; MACHADO, 2010).

A busca pela efetividade do processo em prol de sua missão social de eliminar conflitos e fazer justiça é algo inegável. A doutrina é expressa em considerar insuficiente a garantia do acesso ao Judiciário, exigindo, mais que isso, que a tutela jurisdicional dê-se em prazo razoável para que seja possível a realização do valor justiça. Neste sentido, entende-se que o arcabouço constitucionalmente assegurado de direitos e garantias individuais já contemplava implicitamente esta regra em variadas normas, especialmente as que consagram os princípios do acesso à justiça e do devido processo legal, visto que o cumprimento efetivo do que promovem pressupõe, inelutavelmente, a eficácia e a inseparável tempestividade da apreciação judicial do que se pleiteia.

Nesse sentido, o artigo 125 do Código de Processo Civil, ao disciplinar os poderes do juiz, já previa como seu poder-dever "velar pela rápida solução do litígio" (inciso II). De toda sorte, com a previsão constitucional explícita ocorrida, houve maior solidez deste direito, eliminando eventuais dissídios doutrinários subsistentes, tornando, enfim, irrefutavelmente obrigatória a prestação jurisdicional em prazo razoável, e submetendo o direito em questão ao regime jurídico que detêm aqueles insculpidos no artigo $5^{\circ}$ da Constituição.

A concepção de "razoável duração" repele tanto o atraso da prestação quanto a rapidez anormal, idônea a prejudicar o direito fundamental ao devido processo constitucional.

Trata-se de tempo adequado a solucionar, com justiça, o conflito levado à juízo. Nesse sentido, Hoffman (2005) aponta ser "imprescindível que o processo tenha uma certa duração, maior do que aquela que as partes desejam", porquanto o Estado deve assegurar aos litigantes o devido processo constitucional, a ampla defesa e o contraditório. Nada justifica e ampara, todavia, a interminável espera causada pela tormentosa duração do processo a que os cidadãos brasileiros se vêem, via de regra, submetidos "e da qual, ao final, resta sempre a sensação de injustiça” (HOFFMAN, 2005).

A duração exagerada, acima do que seria suficiente à adequada cognição do magistrado, é agora, de forma expressa, constitucionalmente proscrita.

É inconcebível que em um mundo moderno, capaz de enviar informações de uma parte a outra instantaneamente ou de transmitir uma guerra em tempo real, a burocracia, o formalismo e a falta de estrutura mantenham o Poder Judiciário arcaico e ineficaz. É inadmissível que um processo tenha duração maior que a necessária para assegurar a justa decisão (HOFFMAN, 2005). 
À evidência, a delimitação conceitual da expressão é árdua, uma vez que se trata de cláusula aberta. Uma das características que naturalmente emergem é a adstrição a um tempo mínimo, razoável para o juiz conhecer da causa da forma devida (LEAL JÚNIOR; MACHADO, 2010). Por outro lado, impõe-se ponderação para que o deslinde processual não supere os limites do razoável, já que a eficácia do provimento, invariavelmente, guarda relação com a celeridade de todo o conjunto de atos processuais (LEAL JÚNIOR; MACHADO, 2010).

Esse entendimento já havia sido firmado em oportunidade anterior (LEAL JÚNIOR; MACHADO, 2010), não se vinculando a razoável duração à instantaneidade de julgamento. Ao contrário, a própria expressão torna claro não ser esse seu objetivo. Abrir mão do contraditório, do due process ou de outro princípio processual de igual quilate tão somente geraria injustiça aos litigantes e, em um plano maior, prejuízo à sociedade - contrariando, inegavelmente, o significado do vocábulo "razoável". Não se pode esquecer, entretanto, de que a norma garantidora da razoável duração do processo assegura, ademais, os meios que garantam a celeridade de sua tramitação.

Um processo com duração de tempo razoável é um processo em que há celeridade suficiente para tanto. Isso porque são situações, em sua maioria, de extrema importância para ao menos um dos envolvidos. E o retardamento na definição delas perpetua a insegurança, a incerteza, a angústia e o conflito, razão pela qual a celeridade deve ser buscada.

Quando se fala em razoável duração do processo e celeridade de sua tramitação quer-se, indubitavelmente, a superação da morosidade endêmica verificada no Brasil, causada por uma vasta gama de motivos, os quais devem ser tratados.

É dever do julgador ter papel ativo no que concerne ao zelo pelo cumprimento dos direitos fundamentais, o que equivale, in casu, à ausência de morosidade na entrega da prestação jurisdicional. A letindão verificada no Poder Judiciário cai no conceito de serviço público ineficiente, configurando verdadeira mazela social, tendo em vista que provoca danos econômicos e favorece a especulação e a insolvência, situações indesejadas em qualquer país - trata-se dos denominados "danos marginais" ocasionados pela demora processual. Igualmente, acentua a discriminação entre os que têm a possibilidade de aguardar e os que, esperando, têm tudo a perder. 


\section{REPERCUSSÕES DA DEMORA PROCESSUAL NA ATIVIDADE EMPRESARIAL}

Conforme a lição de Cruz e Tucci (2008), dentre os acontecimentos da natureza que mais inquietam o homem, centra-se o fenômeno tempo. E esse objeto de experimentação em muitos âmbitos repercute, tendo especial relevância nos quadrantes do direito, tanto em âmbito material, quanto processual. Neste último campo, o fator tempo "constitui, desde há muito, a mola propulsora do principal motivo de crise da justiça” (TUCCI, 2008, p.15-16). O problema da sobeja demora do processo "é mesmo tão antigo quanto a própria história do direito processual” (TUCCI, 2008, p.16), fazendose presente mesmo desde a vigência do direito romano.

O resultado do processo não apenas deve outorgar uma satisfação jurídica às partes, como, também, para que essa resposta seja a mais plena possível, "a decisão final deve ser pronunciada em um lapso de tempo compativel com a natureza do objeto litigioso, visto que - caso contrário - se tornaria utópica a tutela jurisdicional de qualquer direito" (BIELSA; GRANÃ apud TUCCI, 2008, p.65).

Assim, no Brasil, com a demora no trâmite processual e na execução da decisão, o prejuízo aos envolvidos é imensurável. Enfrentar, no papel de parte, a morosidade no julgamento de um processo judicial é algo que representa custos incomensuráveis. Não só custos financeiros - os quais, contudo, por si só são de grande monta -, como também custos que não são passíveis de avaliação econômica. Angústia, preocupações, incerteza e insegurança resultam da demora processual e, apesar destes elementos não serem economicamente apreciáveis, em muitas vezes representam maior gravame para as partes do que os prejuízos financeiros que estão sendo ocasionados pela demora.

No que tange a esta diversificada gama de custos outros, José Augusto Delgado (2003, p.10), com acerto, aponta que mesmo os advogados, ao levarem seus casos aos tribunais, submetem-se a uma controvérsia "aparentemente infinda, de alta tortura", cenário que também o é para os demais envolvidos no caso, como o juiz, e, especialmente para as partes. Isso porque "o processo é uma representação material do sofrimento das partes em função da demora, do que ele contém e do que reflete" (DELGADO, 2003, p.10).

Prossegue o autor: 
Digo sempre que os processos têm olhos, ouvidos, esperanças e desgastes emocionais. Os conflitos ali presentes vivem a gritar não somente nas tardes dos nossos gabinetes, onde permanecem guardados em nossos armários, mas ecoam em nossos ouvidos, sonhos, madrugadas e no ambiente das nossas famílias do mesmo modo que ecoam no ambiente das famílias das partes e dos operadores do Direito (DELGADO, 2003, p.10).

Dentre outros motivos, aponta-se a falta de recursos materiais, o excesso de formalidades procedimentais, o alto número de impugnações e a ausência de recursos humanos como obstáculos ao bom funcionamento do Judiciário e a correlata morosidade processual (PINHEIRO, 2003, p.43).

Como é cediço, na prestação jurisdicional, o tempo de espera por uma decisão definitiva gera elevado custo para os envolvidos, porque privados dos bens ou direitos sub judice "durante todos os anos que precedem o efetivo cumprimento da decisão transitada em julgado. Nesse caso, as partes arcam com o custo de oportunidade decorrente da privação dos bens e direitos disputados em Juízo" (PUGLIESE; SALAMA, 2008, p.20).

De acordo com magistrados entrevistados em estudo empírico realizado, a morosidade é reconhecida como o principal problema do Judiciário, bem como o alto custo de acesso (custas judiciais e outros custos), vindo em segundo, seguido pela falta de previsibilidade das decisões judiciais (PUGLIESE; SALAMA, 2008, p.43).

Nessa mesma vereda, em pesquisa realizada com o departamento jurídico de empresas que atuam em setores diversos, o Judiciário dos Estados recebeu baixíssimas notas de $47 \%$ dos entrevistados no que concerne ao quesito agilidade, tanto em relação ao $1^{\circ}$ quanto ao $2^{\circ}$ grau (JUSTIÇA..., 2011, p.45-46). A pesquisa reflete a insatisfação dos empresários com a Justiça brasileira, o que acaba por interferir na celebração de contratos de vulto envolvendo partes de outros países, já que a demora gera cenário de insegurança jurídica, na medida em que um direito violado não reparado de forma tempestiva equivale à perpetuação da lesão. Assim, os impactos econômicos são grandes, e estudos interdisciplinares entre direito e economia neste ponto mostram-se cruciais.

Segundo relatório elaborado pelo Conselho Nacional de Justiça, ingressaram na Justiça Estadual, em 2010, 17,7 milhões de processos. O grupo dos maiores tribunais formado por São Paulo, Rio de Janeiro, Minas Gerais e Rio Grande do Sul responde por $62 \%$ dos casos novos. "No $2^{\circ}$ grupo composto 
por onze tribunais de médio porte ingressaram $28 \%$ dos processos da Justiça Comum ao passo que no $3^{\circ}$ grupo, com doze tribunais, iniciaram apenas $10 \%$ do total de casos novos no período [...]" (CONSELHO, 2011, p.36).

Durante o ano de 2010, tramitaram em torno de 61,8 milhões de processos na primeira instância, "dos quais 46,3 milhões (75\%) já estavam pendentes de baixa desde o início do ano, e 15,5 (25\%) ingressaram naquele ano [...]" (CONSELHO, 2011, p.55).

Adicione-se a isso a verificação de que,

entre os 46,3 milhões de processos pendentes, quase 23,6 milhões concentram--se apenas nos Estados de São Paulo e Rio de Janeiro, o que significa que esses dois tribunais são responsáveis por mais da metade do acervo nacional da Justiça Estadual. É relevante destacar que no TJ-SP, 77\% dos processos em tramitação já estavam pendentes no início do ano e no TJRJ, $82 \%$. Desse modo, é plausível concluir que se apenas esses dois tribunais conseguissem reduzir o volume de seus acervos, o total de casos em tramitação na justiça estadual poderia ser reduzido de forma significativa" (CONSELHO, 2011,p.55).

Analisando-se os casos novos por magistrado, os juízes do Rio de Janeiro recebem o "maior volume de casos novos, com 3.113 processos recebidos durante o ano de 2010, enquanto a média nacional é de 1.407, ou seja, mais do que o dobro. $\mathrm{O}$ segundo e terceiro maiores valores da Justiça estão no Rio Grande do Sul e São Paulo, com 2.473 e 2.162 casos novos por magistrado" (CONSELHO, 2011, p.65).

As pesquisas acenadas confirmam a insuficiência do Poder Judiciário frente à quantidade de processos existentes e refletem o reconhecimento pelos magistrados das mazelas existentes em seu labor, assim como a insatisfação dos empresários com a Justiça brasileira, o que acaba por interferir na celebração de contratos de vulto envolvendo partes de outros países, já que a demora gera cenário de insegurança jurídica, na medida em que um direito violado não reparado de forma tempestiva equivale à perpetuação da lesão. A incerteza no que tange ao tempo da duração processual constitui também fator de insegurança jurídica para os jurisdicionados. Assim, os impactos econômicos da demora processual são inegavelmente grandes.

Conforme indicam Zylbersztajn e Sztajn (2005, p.3), o Direito influencia e é influenciado pela Economia e as organizações influenciam, assim como são influenciadas pelo ambiente institucional: 
É verdade que tanto Direito quanto Economia exercem papel primordial na formação de instituições e organizações. Todavia, é importante ressaltar que estas, por sua vez, influenciam a transformação do sistema jurídico e a consecução de resultados econômicos. As instituições, por seus efeitos sobre os custos de troca e produção, afetam decisivamente a performance econômica e, juntamente com a tecnologia empregada, elas, as instituições, determinam os custos de transação e transformação que formam os custos totais da atividade econômica em determinado ambiente [...].

A percepção de que o mau funcionamento do Poder Judiciário tem impacto de peso sobre o desempenho da economia é relativamente recente e reflete o crescente interesse do papel das instituições como determinante do desenvolvimento econômico (FARIA, 2007).

É indiscutível que a dinâmica existente no mundo empresarial não comporta a demora corrente, retirando, com isso, do Poder Judiciário a legitimidade que se espera enquanto pacificador social por excelência (RODRIGUES, 2009). Segundo Adorno e Pasinato (2007):

No domínio da justiça cível, não são poucos os problemas. As corporações empresariais reclamam que o tempo da intervenção judicial não acompanha o ritmo dos negócios imposto pelo mercado. Problemas decorrentes de morosidade judicial têm sido igualmente apontados em disputas fiscais, indenizações e cobranças de toda sorte. Não sem razão, vimos assistindo, cada vez mais na sociedade, à disseminação de sentimentos coletivos segundo os quais, se a justiça tarda, as leis não são aplicadas.

Consoante Ana Maria Jara Botton Faria (2007) bem pontua, a morosidade na solução dos litígios é fator de inibição de investimentos na economia e a demora na prestação da tutela jurisdicional acarreta vários impactos no setor, sendo um dos resultados o arrefecimento da atividade econômica, que requer segurança jurídica para atuar. Logo, se no momento atual fala-se em aquecimento da economia, é indiscutível que, se fosse corrigida a sobeja demora na duração processual, alcançar-se-ia maior desenvolvimento econômico.

Os investidores somente irão realizar investimento de longo prazo, em especial os altamente especializados, quando e se estiverem seguros de que os contratos que garantem suas atividades serão corretamente implementados; não adianta o instrumento contratual conter regras acerca da forma de 
pagamento, das penalidades aplicáveis, a detalhada especificação de que o pagamento também inclui a remuneração do capital; torna-se necessário que o judiciário seja eficiente, independente, ágil permitindo o devido respeito e cumprimento do contrato firmado. [...] (ADORNO; PASINATO, 2007).

Um judiciário eficiente, que solucione os conflitos em prazo razoável, nos moldes acima delineados, é essencial para que firmas e indivíduos sintamse seguros ao fazer investimentos específicos, sejam eles físicos ou em capital humano. A qualidade do serviço judiciário gera impacto sobre o investimento, especialmente quanto mais especializada for a natureza desse investimento. "De forma geral, os agentes privados só farão investimentos altamente especializados se estiverem seguros de que os contratos que garantem suas atividades serão corretamente implementados" (ADORNO; PASINATO, 2007). Não basta, portanto, que o direito material atenda às expectativas dos cidadãos se o sistema de solução de controvérsias, naquele Estado, é moroso - e, por conseguinte, ineficiente. A ciência de que eventual descumprimento contratual, por exemplo, demorará a ser solucionado - ainda se saiba de antemão que será julgado em seu favor, pela simples análise do direito objetivo - ocasiona insegurança para a parte, levando essa a cercarse de mais garantias, ou, até mesmo, a não celebrar o mesmo negócio.

Segundo estudos realizados, "as deficiências do sistema judiciário no Brasil - caracterizado por lentidão nas decisões referentes à execução judicial das garantias e alto custo das cobranças judiciais - apresentam peso considerável na elevação dos riscos e dos spreads nos empréstimos bancários" (MORAIS, 2006). Assim, a morosidade provoca um custo adicional no crédito: $20 \%$ da composição do spread bancário decorre da lentidão processual, segundo dados do Banco Central do Brasil (SILVA; PINTO, 2012).

Por outro lado, embora a morosidade seja, talvez, o principal dos entraves da efetividade do processo no campo do direito empresarial, não é o único dos existentes.

Em economias mais desenvolvidas, em que a análise econômica do direito se mostra mais avançada, discute-se a questão da deficiência técnica das decisões judiciais em relação a debates ligados ao direito societário. A divergência entre o meio onde se desenvolvem as decisões empresariais e aquele onde são tomadas as decisões judiciais é utilizada como motivo para questionamento da efetividade processual nesta área. Tem-se considerado 
como mais eficaz, até onde seja possível, submeter as decisões de investidores, gerentes e diretores ao julgamento do próprio mercado que ao Poder Judiciário (RODRIGUES, 2010).

A segurança promovida por um Judiciário eficiente - aponta Faria (2007) - serve de regulador da economia e viabilizador dos instrumentos da ordem econômica, "protegendo o mercado do ataque de especuladores, da competição desleal, dos cartéis e monopólios, situações cada vez mais comuns em razão da globalização".

Indica a autora (FARIA, 2007) que a fraca performance do Judiciário na maior parte dos países em desenvolvimento prejudica o desempenho econômico de várias maneiras: reduz a abrangência da atividade econômica, desestimulando a especialização; dificulta a exploração de economias de escala; desencoraja investimentos e a utilização do capital disponível; distorce o sistema de preços ao introduzir fontes de risco adicionais nos negócios; e diminui a qualidade da política econômica. Tem-se, assim, que sem a garantia desta segurança jurídica, muitas transações econômicas ficam "mais caras, raras ou mesmo inexistentes".

A morosidade processual acarreta situações incômodas ao exercício da atividade empresarial das formas mais diversas possíveis: sócios minoritários em conflito com majoritários sobre os rumos da atividade desempenhada; microempresário que pleiteia cobrança de elevado débito de clientes; sociedade empresária buscando restituição de tributos indevidamente pagos, dela exigidos erroneamente; dentre outras. Trata-se de situações corriqueiramente verificadas, nas quais a demora na resolução do conflito prejudica a atividade empresarial.

Não obstante o que já foi trazido, cumpre lembrar que a lei $\mathrm{n}^{\circ} 11.101 / 05$ disciplinou os institutos de falência e recuperação judicial e extrajudicial. Tanto a decretação da primeira como a adoção de qualquer uma das espécies de recuperação submete-se ao crivo jurisdicional. Assim, em situações de crise econômico-financeira, a empresa terá de se submeter ao Poder Judiciário para ser analisada. A morosidade em qualquer destas hipóteses (recuperação ou decretação de falência) contraria em demasia os interesses de todos os envolvidos - sejam credores, devedor, Poder Público ou terceiros.

A apreciação e a decisão do Poder Judiciário em tempo razoável é essencial para que seja possível cogitar de uma recuperação do agente econômico. E mesmo na decretação da falência, a demora processual é prejudicial aos credores, privados de seus créditos, ainda que não seja possível recebê-los de forma integral. 
Enfim, seja a situação que for, tem-se que prejudicando as empresas, que são agentes econômicos, o prejuízo às economias dos países envolvidos é indiscutível, eis que a mera ciência da morosidade processual já é fator possível de espantar investidores externos no espaço brasileiro.

\section{BUSCANDO SUBSÍDIOS NO MODELO PROCESSUAL CIVIL INGLÊS A FIM DE TORNAR MAIS CÉLERE A PRESTAÇÃO JURISDICIONAL NO BRASIL}

Feitas as considerações anteriores, infere-se que a demora processual é fator de desprestígio ao Poder Judiciário brasileiro, gerando impactos mesmo na atividade econômica, na medida em que ocasiona prejuízos de diversas ordens às empresas envolvidas em conflitos de interesses relativos à sua atividade.

A morosidade gera incerteza e insegurança jurídica, fazendo protraíremse no tempo angústia e preocupação dos envolvidos. A notória demora existente no processo civil brasileiro é fator que acaba por prejudicar a inserção das empresas brasileiras no mercado globalizado e diminuir o aquecimento da economia brasileira. Assim sendo, solucionar a mazela da morosidade processual é necessidade premente, especialmente no que tange ao contexto econômico.

O modelo processual civil brasileiro é alvo de críticas de diversas ordens, notadamente no que se refere à demora processual, à grande quantidade de recursos facultados aos litigantes e à ordinarização do procedimento, eminentemente delongado e desprestigiador das características específicas dos direitos buscados.

Neste passo, segundo Cruz e Tucci (1998, p.27), o processo deve, na medida do possível, desenvolver-se mediante um procedimento célere, "a fim de que a tutela jurisdicional emerja realmente oportuna e efetiva". A ideia de efetividade do processo, de fato, está intrinsecamente associada à razoabilidade da duração do feito. E por essa última expressão deve-se entender o tempo adequado à solução justa do conflito, sem qualquer dilação maior que não se volte única e exclusivamente para a obtenção desta meta.

Quer-se, então, um julgamento célere, sem dilações indevidas. Não se cuida de rapidez em sentido pejorativo, isto é, com desmazelo. É essencial certo tempo para a adequada defesa ser preparada, para as provas pertinentes serem produzidas, assim como para o conjunto de dados processuais ser cautelosamente analisado, cabendo lembrar que o juiz lida com uma infinidade de processos simultaneamente, não podendo dedicar-se apenas a um de cada vez. 
Enfim, não se defende prestação imediata de tutela, sem análise das alegações e das provas, adequadamente produzidas na instrução. Reconhecese que a precipitação ofende as garantias processuais constitucionais. Por óbvio, exige-se tempo para conciliar os valores em jogo no processo e as implicações que advêm de uma sentença, a partir da produção de seus efeitos. Mas esse tempo, como se aponta, não deve ultrapassar o razoável.

Assim, é importante desafio do Estado brasileiro contemporâneo a superação da notória morosidade verificada no exercício da função judicante. O poder público e a sociedade devem envidar esforços para tanto.

Nesta senda, o juiz, por exemplo, condutor do processo, tem o poderdever de assegurar sua trajetória regular, e atuar de maneira a impedir retardamentos desnecessários, reprimindo comportamentos abusivos dos litigantes e de qualquer outro envolvido, ordenando de ofício diligências que julgue essenciais à elucidação da causa e indeferindo as de propósito manifestamente protelatório (TUCCI, 1998, p.35-36). Cabe ao magistrado, demais disso, aplicar punição a atuações meramente procrastinatórias, de qualquer das partes ou terceiros que venham a atuar no decurso do feito.

Deve, igualmente, haver controle, por meio do julgador, de corregedorias, e da própria sociedade civil, de condutas negligentes e omissivas de auxiliares e serventuários da justiça, que resultem em injustificável retardo processual. Urge que multas e sanções já previstas em lei passem a ser efetivamente aplicadas, quando cabíveis. Como exemplos, podem ser ventiladas, dentre outras, as seguintes previsões do Código de Processo Civil: artigo 14, parágrafo único; artigo 18; artigo 196; artigo 233; e artigo 424, parágrafo único.

De todo modo, sabe-se que o sistema processual civil pátrio é construído sobre o chamado "procedimento ordinário", rigidamente estruturado dentro da garantia do devido processo legal e caracterizado pelo contraditório prévio e seu esgotamento, o que é inegavelmente fruto de ideologia privilegiadora da segurança jurídica em detrimento da justiça. Assim, há mais apreço pela atividade declaratória dos direitos postos em litígio do que pela sua efetiva proteção $e$ efetivação.

O processo civil inglês, por outro lado, especificamente após a edição das Civil Procedure Rules (CPR), em 1999, pode ser tido como paradigma de valorização da atividade da figura do magistrado. $\mathrm{O}$ ordenamento civil processual britânico está centrado no aumento dos poderes judiciais na condução do processo, no sentido de franquear ao juiz o gerenciamento da causa, com a fixação de técnicas nesta vereda pela lei e que consistiriam em: 
i) estímulo à cooperação mútua das partes na condução do processo; ii) identificação de plano das questões postas em juízo; iii) separação das questões segundo a profundidade da cognição exigida para sua decisão e determinação da ordem em que serão resolvidas; iv) privilégio das soluções alternativas e amigáveis ao conflito; $v$ ) auxílio às partes para resolver parcela ou a totalidade do conflito; planificação antecipada do andamento processual; vi) verificação dos custos das providências necessárias ao deslinde da demanda antes de sua determinação; vii) e concentração do conhecimento das questões envolvidas na causa e redução da necessidade do comparecimento das partes em juízo para a prática dos atos de análise daquelas mesmas questões (ALMEIDA, 2011).

$\mathrm{O}$ rol de poderes-deveres judiciais retromencionado integra a regra 1.4 das CPR e é complementado por outras regras, especialmente a 3.1, cujo conteúdo é meramente exemplificativo. Ou seja, outros poderes podem ser exercidos pelo magistrado, desde que voltados ao alcance do denominado overriding objective (objetivo preponderante), previsto na regra 1.1 do mesmo diploma. E seu objetivo preponderante é a viabilização da solução dos conflitos de interesse com justiça. Para tanto, impõe as seguintes diretrizes: i) assegurar que as partes estejam em iguais condições de disputa; ii) evitar despesas desnecessárias; iii) lidar com os casos de forma proporcional em relação a sua importância, complexidade das questões, valores envolvidos e condições financeiras das partes; iv) assegurar que as ações se processem com celeridade e justiça; e v) distribuir em cada caso os recursos do tribunal de forma equilibrada, levando em conta a existência de outros litígios.

Aspecto interessante é que, até a entrada em vigor das CPR, o processo civil inglês pautava-se pelo princípio do controle das partes, caracterizado pela mínima atuação do julgador na instrução do processo. Isso se devia à filiação do direito inglês ao adversarial system, posto se tratar de Estado em que vige o sistema da common law. O fenômeno resulta de processo natural de aproximação entre os sistemas da civil law e da common law - algo saudável, na medida em que viabiliza real aproveitamento das proficuidades existentes em cada um deles.

Deste modo, sob a égide das CPR, as partes perderam grande parcela do poder quanto ao desenvolvimento do processo, que foi passado, por seu turno, aos magistrados. A promulgação deste diploma constituiu revolução no direito inglês, já que se teve, em verdade, também, a criação de verdadeiro código de processo civil, em país com tradição de direito eminentemente 
costumeiro. Romperam-se, assim, dois arraigados paradigmas lá existentes. Sua origem deu-se em virtude de relatórios elaborados por Lord Woolf, na busca de soluções para os problemas verificados no processo civil inglês, à época reconhecidamente custoso, complexo e patologicamente lento, o que gerava impactos no acesso à justiça (TURNER apud ALMEIDA, 2011).

A esse respeito, Almeida (2011) assevera que o principal objetivo da reforma processual inglesa de 1999 fulcrou-se na mudança de mãos da gestão do tempo e dos atos do processo dos advogados/partes para as mãos dos juízes, e que isso somente foi possível mediante alteração cultural do arraigado sistema adversarial do direito processual inglês para um sistema que agora prima pela cooperação dos envolvidos no processo. As CPR disciplinam esses poderes, na verdade, como deveres do Judiciário ("Court's duty to manage cases", conforme regra 1.4), e possuem maior amplitude mesmo que os existentes em países de tradição inquisitorial, como o Brasil.

No gerenciamento, os juízes conhecem dos casos com maior rapidez e negociam com as partes as fases do procedimento. Esse último aspecto, que atende os princípios do contraditório e da segurança jurídica, pode colaborar na redução de eventual frustração da(s) parte(s), já que se sentem mais participantes no desenvolvimento processual e, consequentemente, na formação da cognição judicial (TAVARES, 2011, p.149). Tem-se, então, o seguinte panorama: o juiz, por meio da gestão da causa, tem a possibilidade de flexibilizar o procedimento, de sorte a adaptá-lo ao que exige o direito material em discussão. Com isso, há maior participação das partes - ouvidas sobre as alterações rituais -, a cognição é otimizada e a duração processual acaba por ser mais adequada ao que o conhecimento da causa exige. No que concerne a lides empresariais, os resultados positivos para o empresariado são inegáveis: duração mais curta, resultados mais acertados e maior segurança, decorrente da diminuição do tempo em que será prestada a tutela jurisdicional.

Nesta trilha, as três funções precípuas da gestão do processo, conduzida pelo juiz, podem ser assim colocadas: i) encorajar as partes a se empenharem, conjuntamente, pela busca da justiça - e não como adversários ferrenhos; ii) evitar que o processo tramite de maneira lenta e ineficaz; e iii) garantir que os recursos do Judiciário sejam utilizados de maneira razoável e proporcional (ANDREWS, 2009).

O direito inglês, ademais, impõe que os envolvidos, sejam partes, advogados ou mesmo peritos, por exemplo, comprometam-se com a busca pela verdade e pela justiça em todos os momentos. A postura acenada guarda direta 
relação com a severidade das sanções impostas àqueles que descumprem este dever (ANDREWS, 2009).

As Civil Procedure Rules tiveram por meta tornar o processo civil inglês mais célere, menos dispendioso e efetivo (procurando-se, com isso, afastar a insatisfação social que até então se observava). O direito inglês, dessarte, passou a ostentar uma tônica próxima da Civil Law e contrária à visão do sistema adversarial, por meio do qual o juiz, assim como ocorre nos Estados Unidos, tem uma posição mais distante. Com efeito, nos termos da legislação inglesa, agora, expressamente incumbe ao juiz uma postura mais reguladora e condutora dos rumos do processo (CARPENA, 2010).

As regras processuais inglesas, assim sendo, expressamente arrolam uma série de medidas que bem demonstram atualmente, de forma exemplificativa, os poderes do juiz naquele país. É a regra $\mathrm{n}^{\circ} 3.1$, já aludida, que registra caber ao juiz: i) dilatar ou encurtar prazos; ii) adiar ou antecipar audiências; iii) ordenar à parte ou ao seu advogado que compareça ao tribunal; iv) determinar a produção de prova por telefone ou pelo uso de qualquer outro método de comunicação oral direta, durante uma audiência; v) determinar que se processe em separado parte da matéria litigiosa; vi) suspender total ou parcialmente o processo; dentre outras. Infere-se, portanto, o poder--dever recebido pelo magistrado para conduzir adequadamente o processo, em busca de celeridade e adequação procedimental, de forma a ser concedida tutela jurisdicional efetiva, adequada e tempestiva.

Não bastasse isso, o sistema processual civil inglês dá prioridade absoluta para as chamadas alternative dispute resolution (ADR), isto é, os meios alternativos de solução de conflitos, o que faz com que haja drástica diminuição do número de processos tramitando no Poder Judiciário. Nesse sentido, logo no início das CPR, prevê-se internamente ao dever gerencial do juiz, "encouraging the parties to use an alternative dispute resolution procedure if the court considers that appropriate and facilitating the use of such procedure" $\left(\right.$ Regra $\left.\mathrm{n}^{\mathrm{o}} 1.4,2, \mathrm{e}\right)$.

Reconhecer isso como diretriz geral do sistema processual civil e criar condições para que isso se efetive, como se dá na Inglaterra, especialmente por meio de incentivos econômicos, aliado a uma devida internalização cultural disso, notadamente pelos juízes, de forma a se obter contingente considerável de soluções alternativas, geraria as seguintes proficuidades: i) diminuição do número de processos, o que leva a redução do volume de trabalho dos juízes e reflete no tempo do julgamento dos demais feitos; ii) minimização do tempo 
levado para se chegar à solução da causa em discussão; iii) mitigação dos custos, tanto econômicos, quanto demais custos pessoais dos envolvidos; e iv) possível manutenção das relações, quando continuativas (o que é extremamente comum em litígios de cunho empresarial), já que nos meios alternativos as partes participam ativamente da solução do conflito, às vezes decidindo-o integralmente (como na mediação) elas mesmas, afastando o caráter de adversariedade entre elas existente durante um processo judicial.

No Brasil, apesar da previsão formal, na prática o juiz se vê em muitas oportunidades limitado. Deste modo, a participação ativa do juiz, de forma ampla e concreta, ou seja, não só formalmente, mas substancialmente, é medida que se impõe em um sistema jurídico que pretenda efetivar, e não somente proclamar, os direitos dos cidadãos.

Assim, a utilização do atual modelo processual civil inglês apresenta-se útil para servir de inspiração ao ordenamento brasileiro, já que valoriza o papel do juiz na condução do processo, o que, inevitavelmente, prestigia a cognição, a qual se coloca como importante instrumento processual em favor da devida tutela de direitos, já que tal atividade jurisdicional, por meio dos modos pelos quais pode ser utilizada, tem o condão de formar técnicas processuais diferenciadas.

Essa cognição adequada, amoldada a cada caso, vincula-se necessariamente a ideia de realização de justiça e, para Watanabe (2000), ligase ao princípio do juiz natural. $\mathrm{O}$ autor afirma que há um direito à cognição adequada à natureza da controvérsia, contido no princípio do devido processo legal. Dele é resultado assim como os demais princípios processuais constitucionais (motivação, contraditório, ampla defesa, dentre outros). "Devido processo legal é, em síntese, processo com procedimento adequado à realização plena de todos esses valores e princípios" (WATANABE, 2000, p.124), voltados à efetividade da tutela jurisdicional.

Assim, do devido processo extrai-se, como corolário inafastável, o direito à cognição adequada à natureza da controvérsia. Infere-se verdadeira dependência entre cognição adequada e razoável duração do processo, na medida em que, por meio de um rito adaptado ao direito material em discussão, ter-se-á, ao menos em tese, uma duração temporal razoável para a análise que o específico objeto requer (LEAL JÚNIOR; BALEOTTI, 2011).

Com o fortalecimento da figura do magistrado no contexto inglês, tem-se a possibilidade de que ele trabalhe com o procedimento de forma a obter a melhor cognição possível e uma duração mais adequada ao objeto em discussão. A reforma que propiciou essa nova sistemática, ora elogiada, foi considerada 
exitosa logo após três anos da adoção das CPR. O tempo médio para julgamento de um processo em $1^{\circ}$ grau, que em 2007 era de 639 dias, passou, em 2000/ 2001 para 498 dias (GAJARDONI, 2008). Portanto, houve notória agilização da prestação jurisdicional.

Por força disso, inúmeros contratos comerciais estrangeiros contêm, atualmente, cláusula de eleição de tribunais ingleses para solução de eventual conflito. Em metade dos casos julgados pela Commercial Court de Londres os litigantes não são residentes na Inglaterra ou no País de Gales (ALMEIDA, 2011, p.326). A doutrina inglesa é praticamente unânime em reconhecer as vantagens advindas da reforma, uma vez que "casos que normalmente permaneceriam cinco anos sem julgamento são atualmente solucionados entre quinze a dezoito meses" (ALMEIDA, 2011, p.326).

Enfim, a percepção da comunidade jurídica inglesa é de que houve aprimoramento da justiça civil, agora mais célere e eficaz. A incorporação dos aspectos referidos, tais como a possibilidade de flexibilização procedimental e o efetivo fomento à utilização de meios alternativos de solução de controvérsias, não prejudicariam a sistemática constitucional brasileira, uma vez que há abertura para isso. Certamente, ter-se-ia, então, um processo que melhor pudesse se adequar às situações específicas exigidas, tais como em que houve envolvimento de negócios jurídicos empresariais. Destaca-se, nesta linha, que a reforma empreendida no direito processual inglês teve como um de seus objetivos "tornar o processo civil mais acessível para as pessoas comuns e empresários" (ALMEIDA, 2011, p.296) [grifo nosso].

Entretanto, estas modificações, que, inclusive, poderiam vir alinhavadas na proposta de criação de novo Código de Processo Civil (projeto n ${ }^{\circ}$ 8.046/ 2010) exigiriam, ainda, mudanças culturais, de forma que as partes internalizassem a concepção de ser mais vantajosa a solução às vezes negociada do conflito ou a atuação em favor da efetiva resolução e conclusão do processo, para que colaborassem, então, no trâmite processual, não obstaculizando seu decurso e nem prolongando, de alguma forma os prazos processuais.

\section{CONCLUSÕES}

Pode-se afirmar que a temática em apreço detém notória e inegável importância. Não são novos os debates acerca da morosidade existente no Poder Judiciário brasileiro e da necessidade de alteração desta situação para que se alcance real eficácia no provimento jurisdicional buscado. A insegurança e a incerteza geradas pela elevada demora para o desfecho processual não 
interessa à sociedade, tampouco a algum dos litigantes, exceto àqueles que buscam tão somente a protelação - por seu interesse falecer justo motivo.

A indiscutível lentidão no tramitar processual causa desprestígio ao Judiciário e macula o fundamento existencial da tutela pretendida, porquanto sua duração desarrazoada, ocasionalmente, tem o condão de permitir o fenecimento do bem da vida pleiteado. Tendo isto assente, tornou-se crível, no decorrer deste feito, chegar a certas ilações.

A partir da emenda constitucional $n^{\circ} 45 / 2004$, foi acrescentado, de forma expressa, novo direito fundamental e sua respectiva garantia no elenco que forma o artigo $5^{\circ}$ - o princípio da razoável duração do processo, que contempla o direito de se exigir eficiência e prontidão da resposta estatal à provocação ocorrida por meio de demanda intentada.

Com a demora no trâmite processual e na execução da decisão, o prejuízo aos envolvidos é incomensurável. Enfrentar, no papel de parte, a morosidade no julgamento de um processo é algo que representa custos imensuráveis. Não só financeiros como também custos que não são passíveis de avaliação econômica, como angústia, preocupações, incerteza e insegurança.

Isso é mais gravoso ainda, pelos inúmeros reflexos que gera, quando se trata de agentes econômicos envolvidos e negócios jurídicos empresariais em discussão: os impactos econômicos da demora processual são inegavelmente grandes. A dinâmica existente no mundo empresarial não comporta a lentidão judicial na solução dos litígios, de sorte que essa atua como fator de inibição de investimentos na economia.

O fraco desempenho do Poder Judiciário prejudica a economia de diversas maneiras: reduz a abrangência da atividade econômica; dificulta a exploração de economias de escala; desencoraja investimentos e a utilização do capital disponível; distorce o sistema de preços ao introduzir fontes de risco adicionais nos negócios; e diminui a qualidade da política econômica. Logo, sem a segurança de que os conflitos sub judice serão julgados em tempo razoável, muitas transações econômicas ficam mais caras, raras ou mesmo inexistentes.

A lei $n^{0} 11.101 / 05$, que trata da falência e recuperação judicial e extrajudicial, para que alcance efetividade no propósito de valorizar a função social da empresa, a preservação da atividade econômica e o respeito ao melhor interesses dos credores, impõe que a tutela jurisdicional seja prestada em tempo breve. Em situações de crise econômico-financeira, portanto, a empresa, que terá de se submeter ao Poder Judiciário para ver aquela analisada, vivenciando contexto de morosidade, verá contrariados em demasia os interesses de todos os nela envolvidos (credores, devedor, Poder Público e terceiros). A apreciação 
e a decisão do Poder Judiciário em tempo razoável é essencial para que seja possível cogitar de uma recuperação do agente econômico. E mesmo na decretação da falência, a demora processual é prejudicial aos credores privados de seus créditos, ainda que não seja possível recebê-los de forma integral.

Enfim, seja a situação que for, tem-se que, prejudicando as empresas, que são agentes econômicos, o prejuízo às economias dos países envolvidos é indiscutível, eis que a mera ciência da morosidade processual já é fator possível de espantar investidores externos no espaço brasileiro.

Aspectos do atual sistema processual civil inglês são apresentados, então, como paradigma, a fim de que no espaço brasileiro haja, igualmente, maior valorização da figura e mister do magistrado, de forma a ser tentada a redução da demora processual e ser concedido o provimento jurisdicional, então, adequado, tempestivo e efetivo. Enfim, a importação de elementos tais como a flexibilização procedimental e os incentivos às ADR podem funcionar como mecanismos de auxílio no combate às mazelas do Judiciário brasileiro, especialmente se acompanhados de mudança cultural da população, bem como de maior aporte financeiro para aumentar a infraestrutrura e os recursos humanos.

\section{REFERÊNCIAS}

ADORNO, Sérgio; PASINATO, Wânia. A justiça no tempo, o tempo da justiça. Tempo Social: revista de sociologia da USP, São Paulo, v. 19, n. 2, p.131-155, nov. 2007.

ALMEIDA, Diogo Assumpção Rezende de. O Case Management inglês: um sistema maduro? Revista Eletrônica de Direito Processual. Rio de Janeiro, ano 5, v.7, p.288-338, jan./jun. 2011.

ANDRADE, Érico. As novas perspectivas do gerenciamento e da "contratualização" do processo. Revista de processo, São Paulo, ano 36, n.193, mar. 2011.

ANDREWS, Neil. O moderno processo civil. São Paulo: Revista dos Tribunais, 2009.

BEDAQUE, José Roberto dos Santos. Direito e processo. 6.ed. São Paulo: Malheiros, 2011. 
BUENO, Cássio Scarpinella. Curso sistematizado de direito processual civil. 4.ed. São Paulo: Saraiva, 2010. v.1.

CAPPELLETTI, Mauro; GARTH, Bryant. Acesso à justiça. Porto Alegre: Sergio Fabris, 1988.

CARPENA, Márcio Louzada. Os poderes do juiz no common law, Revista de processo, São Paulo, v.35, n.180, fev. 2010.

CONSELHO NACIONAL DE JUSTIÇA. Justiça em números. Brasília: CNJ, 2011.

DELGADO, José Augusto. Constitucionalidade da mediação. In: CADERNOS CEJ. Mediação: um projeto inovador. Brasília: Centro de Estudos Judiciários, 2003.

FARIA, Ana Maria Jara Botton. Judiciário e economia: equalização desejada e necessária. Revista direitos fundamentais e democracia, Curitiba, v.2, n.2, jun./dez. 2007. Disponível em: $<$ http:// revistaeletronicardfd.unibrasil.com.br/index.php/rdfd $>$. Acesso em: $01 \mathrm{mar}$. 2012.

GAJARDONI, Fernando da Fonseca. Flexibilização procedimental. São Paulo: Atlas, 2008.

GUERRA, Marcelo Lima. Antecipação de tutela no processo executivo. Revista de Processo. São Paulo, v. 87, ano 22, jul./set. 1997.

HOFFMAN, Paulo. O direito à razoável duração do processo e a experiência italiana. Jus Navigandi, Teresina, ano 10, n. 782, 24 ago. 2005. Disponível em: <http://jus.com.br/revista/texto/7179>. Acesso em: 3 jan. 2012.

JUSTIÇA E ECONOMIA. Etco, São Paulo, ano 8, n.18, jan. 2011. p.45-46.

LEAL JÚNIOR, João Carlos; BALEOTTI, Francisco. Conexões entre cognição adequada e razoável duração do processo: análise sob o 
prisma do acesso à justiça. In: ENCONTRO CIENTÍFICO DE ESTUDOS EM DIREITOS HUMANOS, 5., 2011, Londrina. Anais... Londrina: UEL, 2011.

; MACHADO, Denise Maria Weiss de Paula. Análise crítica do duplo grau de jurisdição sob o prisma do direito à razoável duração do processo. Revista de Processo, São Paulo, n. 183, a.35, p.77-118, maio 2010.

LENZA, Pedro. Direito Constitucional Esquematizado. 8.ed. São Paulo: Método, 2005.

MARINONI, Luiz Guilherme. Derecho fundamental a la duración razonable del proceso. Reforma Judicial: Revista Mexicana de Justicia, Cidade do México, n.14, p.35-51, jul./dez. 2009.

MARINS, James. Processo instantâneo versus processo razoável: a dualidade temporal da garantia constitucional. Novos estudos jurídicos, Itajaí, v.16, n.02, p. 188-206, mai./ago. 2011.

MORAIS, José Mauro de. Empresas de pequeno porte e as condições de acesso ao crédito: falhas de mercado, inadequações legais e condicionantes macroeconômicos. Texto para discussão, Brasília, n.1189, jun. 2006.

PAROSKI, Mauro Vasni. Do direito fundamental de acesso à justiça. Scientia iuris, Londrina, v.10, p.225-242, 2006.

PINHEIRO, Armando Castelar. Judiciário, reforma e economia: a visão dos magistrados. Texto para discussão, Rio de Janeiro, n. 966, jul. 2003.

PUGLIESE, Antonio Celso Fonseca; SALAMA, Bruno Meyerhof. A economia da arbitragem: escolha racional e geração de valor. Revista GV, São Paulo, v.7, p.15-28, jan./jun. 2008.

ROJAS, Claudio Nash. La concepción de derechos fundamentales en Latinoamerica: tendencias jurisprudenciales. 2008. Trabalho de Conclusão de Curso (Doutorado em Direito) - Universidad de Chile, Santiago. 
RODRIGUES, Pedro Paulo Moreira. A execução específica dos acordos de acionistas. 2009. Trabalho de Conclusão de Curso (Mestrado em Direito) - Faculdade de Direito Milton Campos, Nova Lima.

A execução específica dos acordos de acionistas, 2010.

Disponível em: < http://www.pvb.adv.br/site/artigos/a-execucaoespecifica-dos-acordos-de-acionistas/>. Acesso em: 01 out. 2011.

SILVA, Lucio Melre da; PINTO, Paulo Roberto. Judiciário e Certificação Digital: Avanços e desafios. Disponível em: <http:/www.iti.gov.br/twiki/pub/ OLD/Main/PalesCart2006/6_Painel_5-Poder_Judiciario-Paulo_PintoSTF.pdf>. Acesso em: 02 fev. 2012.

TAVARES, Luiz Marcelo Cabral. Perspectivas da flexibilização procedimental na experiência brasileira em face do substitutivo do Senador Valter Pereira ao projeto de lei no Senado $n^{0} 166$, de 2010. Revista eletrônica de direito processual. Rio de Janeiro, ano 5, v.7, p.136-157, jan./jun. 2011.

TUCCI, José Rogério Cruz e. Tempo e processo. São Paulo: Revista dos Tribunais, 1998.

WAMBIER, Teresa. Glossário. In: ANDREWS, Neil. O moderno processo civil. São Paulo: Revista dos Tribunais, 2009.

WATANABE, Kazuo. Da cognição no processo civil. 2.ed. Campinas: Bookseller, 2000.

ZYLBERSZTAJN, Decio; SZTAJN, Rachel. Análise econômica do direito e das organizações. In: Direito \& Economia. Rio de Janeiro: Campus, 2005.

Submetido em: 01/12/2012

Aprovado em: 11/07/2013

Como citar: BALEOTTI, Francisco Emílio; JÚNIOR, João Carlos Leal. Impactos da morosidade judicial na atividade empresarial e a busca de soluções no modelo processual britânico. Scientia Iuris, Londrina, v.17, n.1, p.65-90, jul.2013. DOI: 10.5433/2178-8189. 2013v17n1p65. 